\title{
EGFR/erB-1, HER2/erB-2, CK7, LP34, Ki67 and P53 expression in preneoplastic lesions of bronchial epithelium: an immunohistochemical and genetic study
}

\author{
Vítor Sousa • Joana Espírito Santo • Maria Silva • \\ Teresa Cabral • Ana Maria Alarcão • Ana Gomes • \\ Patrícia Couceiro • Lina Carvalho
}

Received: 14 September 2010 /Revised: 20 January 2011 / Accepted: 16 February 2011 / Published online: 22 March 2011

(C) Springer-Verlag 2011

\begin{abstract}
A prognostic interpretation of preneoplastic lesions would have impact in bronchial carcinoma early diagnosis and through the study of Erb-B family receptors as they have an important role in lung carcinogenesis. The existence of drugs as tyrosine kinase inhibitors stressed the importance of studying gene alterations for selected chemoprevention schemes and characterization of carcinogenesis. Bronchial preneoplastic lesions were characterized by immunohistochemistry using the antibodies LP34 (high weigh molecular cytokeratin), CK7, chromogranin A, Ki67, p53, C-erbB-2 and EGFR. HER2 and EGFR gene copy number was also evaluated by fluorescent in situ hybridization in those lesions. The expected results defined the origin cell for basal cell hyperplasia and squamous metaplasia as adaptative lesions and dysplasia. By known experiences and published data, beyond the stem cell, the spectral evolution of bronchial preneoplastic lesions was demonstrated by characterizing basal cells (LP34) and their neoplastic potentiality. Dysplasias showed a higher expression of EGFR, Ki67 and p53 with a stepwise increase with the gravity of the respective grading. C-erbB-2 immunohistochemical over-
\end{abstract}

Sources of support CIMAGO-Centro de Investigação em Meio Ambiente, Genética e Oncobiologia; ROCHE PHARMACEUTICALS

V. Sousa · J. E. Santo $\cdot$ M. Silva $\cdot$ T. Cabral • A. M. Alarcão

A. Gomes $\cdot$ P. Couceiro $\cdot$ L. Carvalho $(\bowtie)$

IAP-FMUC-Institute of Pathology, Faculty of Medicine,

University of Coimbra,

3000-054 Coimbra, Portugal

e-mail: 1carvalho@huc.min-saude.pt

V. Sousa $\cdot$ L. Carvalho

Pathology Institute, Coimbra University Hospital,

Coimbra, Portugal expression was a rare event in preneoplastic lesions. Polysomy was the main mechanism for EGFR and HER2/ neu higher gene copy number and together with increased proliferation index (Ki67) will account to preview bronchial carcinogenesis.

Keywords Bronchial squamous metaplasia. EGFR, HER2/c-erB-2 $\cdot$ CK $7 \cdot$ LP34

\section{Introduction}

Lung cancer is the leading cause of death by malignancy in developed countries and throughout the world. Environmental and occupational exposures, such as polyaromatic hydrocarbons, radon, asbestos, nickel, arsenic and chromium, are important determinants of lung cancer risk, but cigarette smoking is the main risk factor, accounting for about $90 \%$ of the cases in men, $70 \%$ of the cases in women and within today ex-smokers comprising nearly $50 \%$ of all new lung cancer cases [1-5].

The overall 5-year survival rate for lung cancer patients remains less than $15 \%$ [6], and the death rate for lung cancer exceeds the combined total for breast, prostate and colon cancer in developed countries [5]. The major reasons for the poor prognosis for lung cancer are the lack of effective screening and early diagnosis procedures, the propensity for early metastasis and the inability of systemic therapies to cure patients with widely metastatic disease [7]. Lung cancer is the result of a multi-step accumulation of genetic and/or epigenetic alterations; therefore, a better understanding of the molecular mechanism, by which these alterations affect lung cancer pathogenesis, would provide new and more effective strategies for chemoprevention, 
early diagnosis and targeted treatment [8]. The existence of novel drugs against specific molecular targets like EGFR and HER $2 /$ neu genes leads to the importance of defining their expression as biomarkers in preneoplastic lesions.

The 1999/2004 WHO lung tumour classification recognizes three types of preinvasive lesions: squamous dysplasia and carcinoma in situ (CIS); atypical adenomatous hyperplasia and diffuse idiopathic pulmonary neuroendocrine cell hyperplasia [9]. Respiratory epithelium adaptative lesions include basal cell hyperplasia, squamous metaplasia, followed by dysplasia and CIS, which precede or accompany microinvasive or invasive carcinoma. Hyperplasia and squamous metaplasia are considered reversible lesions, while dysplasia and CIS are not [10-15].

Squamous metaplasia as a common adaptative lesion of the bronchial mucosae, especially in smokers, represents a precursor step in the development of invasive squamous cell carcinoma, deserving an accurate study to define its evolutionary potential to lung cancer, in order to be determined in bronchial biopsies [10, 14, 16, 17].

Several molecular and genetic abnormalities have been described in lung carcinogenesis, including activation of proto-oncogenes and loss of tumour suppressor genes and DNA repair genes. Proto-oncogenes can be activated by point mutations, amplification, chromosomal rearrangement and expression of a high gene copy number. [18-20]. Those genomic and molecular abnormalities are early events in lung carcinogenesis and can persist in bronchial lesions for months or years and their persistence or regression have been correlated with lesions' evolution [15, 21-30]. Molecular changes are recognized not only in lung cancer, but also in bronchial epithelium and parenchyma of current and former smokers without the development of lung cancer [31,32].

Epidermal growth factor receptor (EGFR; $E r b B-1$ gene) and ErbB-2 (HER2/neu) belong to ErbB family, a family of tyrosine kinase receptor proteins that includes also ErbB-3 (HER-3) and ErbB-4 (HER-4). The ErbB receptors are composed of three major domains: an extracellular ligand binding; a transmembranar segment and a cytoplasmic with tyrosine kinase activity. ErbB receptor function begins upon ligand binding and is followed by receptor homo (e.g. Erb-1/ Erb-1) or heterodimerization (e.g. Erb-1/Erb-2), activating the tyrosine kinase domain of the receptor, which becomes phosphorylated and acts as a docking site for downstream signalling molecules and cytoplasmic messenger proteins that then trigger a cascade of cytoplasmic and nuclear pathways [15].

It has been suggested and supported by experimental data that aberrant activation of the kinase activity of ErbB receptors plays an important role in the neoplastic transformation and progression, prognosis, survival and resistance to cytotoxic therapies [6, 7, 15, 33-38]. EGFR's high expression is an early event in preneoplastic lesions, with an increasing expression from normal mucosae to hyperplasia, metaplasia and dysplasia [6, 38-42]. EGFR is overexpressed in $84 \%$ of squamous cell carcinoma, $65 \%$ of adenocarcinomas and $68 \%$ of large cell lung carcinomas [41]. As it seems, that ErbB2 is also highly expressed in bronchial preneoplastic lesions and its overexpression is less common in carcinomas (less than $35 \%$ of non-small cell lung carcinomas (NSCLC), mainly adenocarcinomas) [18, 41, 43]. The heterodimer EGFR/HER2-neu has been shown to have a stronger proliferative effect than the corresponding homodimers [38, 44-46]. Amplification and polysomy of EGFR and HER2-neu and overexpressed proteins have been related to survival in patients with NSCLC (non- small cell lung cancer), but contradictory results have been published [47-51]. New therapies have also been developed recently directed to these two molecular targets, some of them being applied in chemoprevention trials, stressing the necessity to understand their expression in adaptative and preneoplastic lesions [5, 5256]. This study concerned bronchial preneoplastic lesions observed in biopsies as basal cell hyperplasia, squamous metaplasia and dysplasia. Using immunohistochemistry, those lesions were characterized by antibodies applied against LP34, CK7, chromogranin A, Ki67, p53, C-erbB2 and EGFR. HER 2 and EGFR gene copy number was also evaluated by fluorescent in situ hybridization (FISH), using normal controls. The aim of the present study is to achieve a better understanding of the spectral evolution of bronchial adaptative and preneoplastic lesions, by recognizing the expression of EGFR and HER2-neu as potential biomarkers for lung cancer risk assessment. This knowledge would help to provide new and more effective strategies for chemoprevention, early diagnosis and targeted treatment.

\section{Materials and methods}

\section{Material}

A number of 67 bronchial biopsies were included in this study, comprising 89 preneoplastic lesions, selected from recent data base, by considering the preservation, number and dimension of the small fragments obtained by bronchial fibroscopy and represented 16 basal cell hyperplasia, 40 squamous metaplasia and 33 epidermoid dysplasia (7 mild dysplasia, 7 moderate dysplasia, 4 severe dysplasia and 15 CIS) (Fig. 1a, b, c, d, e); in 22 cases there was concomitancy of the lesions. The population consisted of 57 men and 10 women, with 66.3 years as mean age (range 38-92).

Hyperplasia was defined when more than four basal cell layers were observed. Squamous metaplasia was considered when there was replacement of ciliated columnar epithelium by pavimentous epithelium without atypia. Dysplasia 

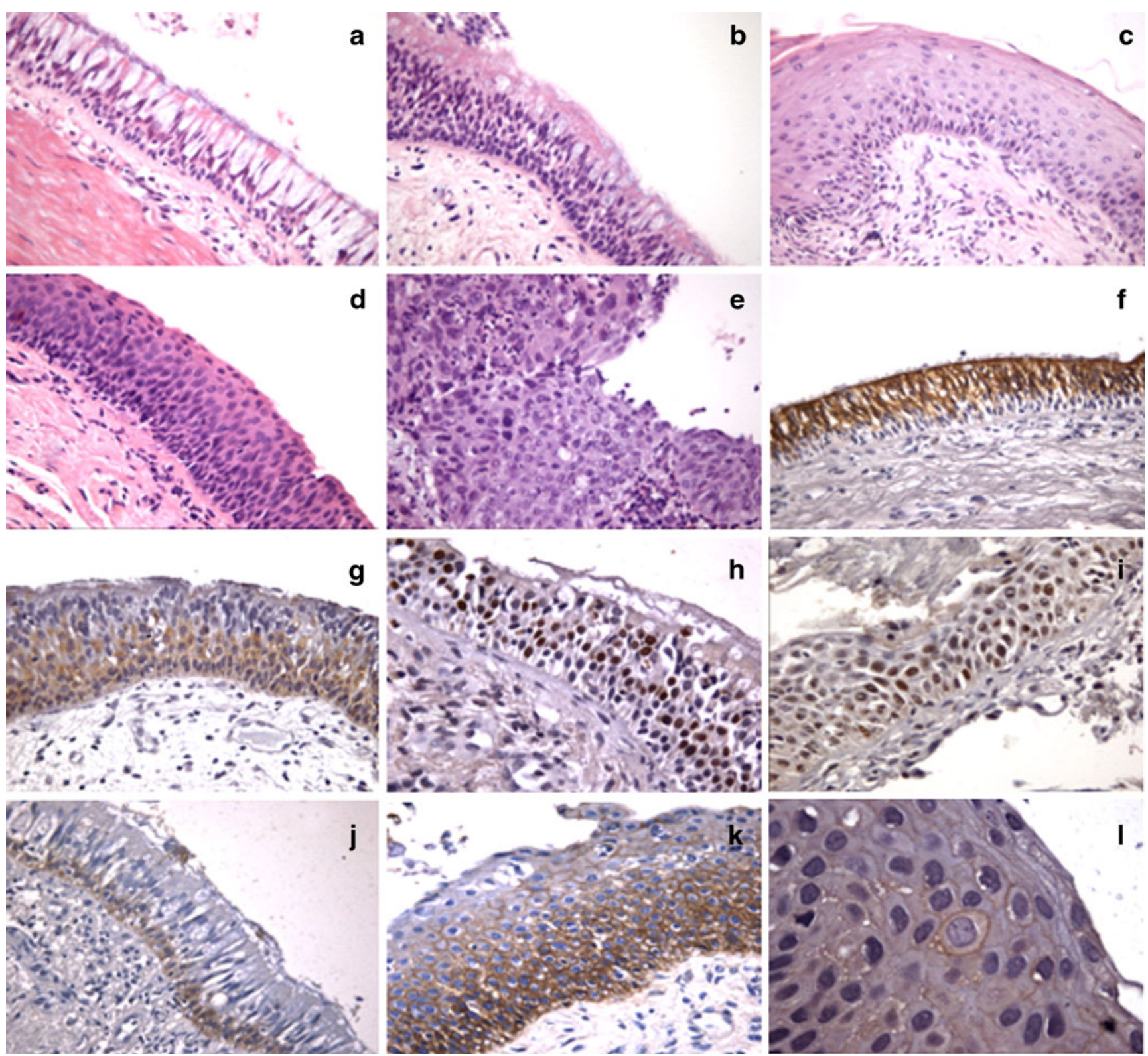

Fig. 1 Morphology and immunostaining: a Normal bronchial epithelium, H\&E, $\times 400$. b Basal cell hyperplasia, H\&E, $\times 400$. c Squamous metaplasia, H\&E, $\times 400$. d Moderate dysplasia, $H \& E, \times 400$. e In situ carcinoma, H\&E, $\times 400$. f CK7 expression, normal

bronchial epithelium, $\times 400$. g Basal cell hyperplasia, LP34, $\times 400$. h Ki67 3+/70\%, ×400. i P53 2+/50\%, ×400. j EGFR negative, normal epithelium, $\times 400$ k EGFR, 3+/60\%, $\times 400$. I C-erbB-2, 2+, $\times 1,000$

1999/2004 histological WHO/IASLC classification of preinvasive squamous lesions of the bronchi.

Methods

\section{Immunohistochemistry}

The imunnohistochemical analysis included seven different antibodies: CK7 (Monoclonal Mouse Anti-human, OV-TL 12/30, Dako); LP34 (Monoclonal Mouse Anti-human, Clone LP34, Dako); chromogranin A (Monoclonal Mouse criteria for preneoplastic bronchial lesions according to the 
Anti-human, Clone DAK-A3, Dako); Ki67 (Monoclonal Mouse Anti-human, Clone MIB-1, Dako); p53 (Monoclonal Mouse Anti-human, Clone DO-7, Dako); C-erbB-2 (Policlonal Mouse Anti-human, Dako) and EGFR (Monoclonal Mouse Anti-human, Clone 31G7, Zymed Laboratories Inc.). The procedure was performed according to a standard avidin-biotin-peroxidase complex. Threemicrometer tissue sections were placed on coated slides and allowed to dry overnight. After deparaffinization and rehydration, antigen unmasking was performed using Module PT (Lab Vision ${ }^{\circledR}$ ) for citrate buffer for $25 \mathrm{~min}$ at $\mathrm{pH} 6,98^{\circ} \mathrm{C}$ for chromogranin A, p53, Ki67 and c-erbB2 antibodies. Antigen unmasking was performed with Pronase E, for $10 \mathrm{~min}$ at room temperature for CK7, LP34 and EGFR antibodies. Endogenous peroxidase activity was quenched using 15 min incubation in $3 \%$ diluted hydrogen peroxide $\left(\mathrm{H}_{2} \mathrm{O}_{2}\right)$. For blocking nonspecific binding, Ultra V Block (Ultra Vision Kit ${ }^{\circledR}$; TP-015-HL) was applied to the sections and then they were incubated at room temperature, with primary antibodies against $\mathrm{CK} 7$ at a dilution of $1 / 50$ for $30 \mathrm{~min}, \mathrm{LP} 34$ at a dilution of $1 / 100$ for $60 \mathrm{~min}$, chromogranin $\mathrm{A}$ at a dilution of $1 / 300$ for $30 \mathrm{~min}, \mathrm{p} 53$ at a dilution of $1 / 40$ for $30 \mathrm{~min}$, Ki67 at a dilution of 1/50 for $30 \mathrm{~min}, \mathrm{c}-\mathrm{erbB}-2$ at a dilution of $1 / 40$ for $60 \mathrm{~min}$ and EGFR at a dilution of $1 / 20$ for $30 \mathrm{~min}$. After washing with phosphatebuffered saline, slides were incubated with biotin-labelled secondary antibody (Lab Vision ${ }^{\circledR}$ ) for 15 min. Primary antibody binding was localized in tissues using peroxidaseconjugated streptavidin (Lab Vision ${ }^{\circledR}$ ) and 3,3-diaminobenzidine tetrahydrochloride was used as the chromogen according to manufacturer's instructions. The slides were counterstained with hematoxylin, dehydrated and mounted.

For each biopsy, external and the intrinsic positive control were considered: basal cells for LP34 and columnar ciliated cells for CK7 in normal bronchial epithelium; carcinoid tumour sections for chromogranin A; sections of a colonic tubulo-villous adenoma for p53; female breast ductal carcinoma in situ for C-erbB-2 and sections of lung adenocarcinoma with intense EGFR IHC positivity. Ki67 was validated by a small cell lung carcinoma.

LP34, CK7 and chromogranin A expression were classified as negative if there was no expression or mild focal expression or positive when there was moderate or intense and diffuse expression. The cut off to classify a lesion as positive for proliferative marker Ki67 was 10\% in at least two layers of positive nuclei above the epithelial basal membrane, since it is normal to observe some proliferative activity mainly in the basal cell layer.

A score established by other authors was applied to Ki67, p53 and EGFR protein expression: 0-negative; 1-focal positivity; 2-mild positivity; 3-moderate positivity; 4-intense positivity. The intensity was multiplied by the percentage of positive cells, thus defining a $0-200 \%$ score as negative or low expression, $201-300 \%$ score as intermediate expression and a $301-400 \%$ score as high expression [19].

The expression of C-erbB-2 was validated by membrane staining and an identical score to the one used in breast cancer was applied with some alterations because of the limited number of cells observed. Each specimen was scored semi-quantitatively according to the intensity of membrane immunostaining in a 4-point scale: 0/negative absence of staining; + - weak staining and/or no homogeneous staining; ++ - moderate homogeneous membrane staining; +++ - intense homogeneous membrane staining. For the ++ and +++ , we registered the number/percentage of stained cells. Cytoplasmic staining was not considered when present.

\section{Fluorescence in situ hybridization (FISH)}

Sections of formalin-fixed paraffin-embedded specimens, 4$\mu \mathrm{m}$ thick, were incubated at $65^{\circ} \mathrm{C}$ for $24 \mathrm{~h}$, deparaffinized in two xylene washes for $10 \mathrm{~min}$ and dehydrated in ethanol. The slides were then incubated at $120^{\circ} \mathrm{C}$ for 4 min with $10 \mathrm{mM}$ citrate buffer (ph 6.0), followed by saline sodium citrate buffer $(2 \times \mathrm{SCC} \mathrm{pH} 7.0)$ washes. Sections were digested with proteinase $\mathrm{K}(0.25 \mathrm{mg} / \mathrm{ml}$ in $2 \times \mathrm{SCC}$, Sigma, $\mathrm{pH} 7.0)$ for $5 \mathrm{~min}$ at $37^{\circ} \mathrm{C}$, followed by new $2 \times \mathrm{SCC}$ wash and post-fixation with $1 \%$ formalin for $10 \mathrm{~min}$ at room temperature. The slides were later on dehydrated in ethanol series $(70-90-100 \%)$ for $2 \mathrm{~min}$. Dual-colour FISH assays for HER2 were performed by using Qbiogene HER2/neu (17q21)/Alphasatellite 17 dual colour probe, and for EGFR, the Vysis, Inc. USA LSI EGFR Spectrum Orange/CEP 7 Spectrum Green probe was used. Ten-microliter probe set was applied to the selected area of the slides and the hybridization areas were covered with a glass cover slip and sealed with rubber cement. The slides were incubated at $90^{\circ} \mathrm{C}$ for $6 \mathrm{~min}$ for co-denaturation and at $37^{\circ} \mathrm{C}$ for $12-18 \mathrm{~h}$ for hybridization in a humidified chamber. Posthybridization washes were performed with $50 \%$ formamide/ $2 \times \mathrm{SCC}(\mathrm{pH} 7.0)$ at $46^{\circ} \mathrm{C}$ for $5 \mathrm{~min}$, followed by $2 \times \mathrm{SSC}$ at $46^{\circ} \mathrm{C}$ for $2 \mathrm{~min}$. After dehydratation in ethanol series, $4^{\prime}, 6^{\prime}$ diamidino-2-phenylindole (DAPI; $0.15 \mathrm{mg} / \mathrm{ml}$ in Vectashield mounting medium, Vector Laboratories, Bulingame, CA, USA) was applied for chromatin counterstaining.

Microscopic analysis was performed on a Nikon Eclipse $80 \mathrm{i}$ bright field and epifluorescent microscope equipped with LUCIA cytogenetics software. Fluorescence signals were scored using single-band filters for DAPI, FITC, Texas Red and triple-band pass filter (DAPI, FITC and Texas Red). Images were recorded with a Nikon digital DMX $1200 \mathrm{~F}$ camera in monochromatic layers, which were subsequently merged by Nikon ACT-1 capture software.

The reference slide (stained with haematoxylin-eosin) usually contained normal bronchial epithelium adjacent to the adaptative and preneoplastic lesions and at least 100 non- 
overlaping interphase nuclei were scored in each fragment for both HER2 and chromosome17 centromer signals and for $E G F R$ and chromosome7 centromer signals, following scoring guidelines and constant adjustments of microscope focus when signals were located at different levels.

Two independent observers performed analysis in a blinded study and scored results, restricted to the selected lesions and bronchial epithelium in each case, with reproducible results.

Six major FISH patterns were identified: disomy $(\leq 2$ gene copies per nucleus in $>90 \%$ of cells); low trisomy ( $\leq 2$ gene copies per nucleus in $\geq 40 \%$ of cells, 3 gene copies in $10-40 \%$ of cells, $\geq 4$ gene copies in $<10 \%$ of cells); high trisomy ( $\leq 2$ gene copies per nucleus in $\geq 40 \%$ of cells, 3 gene copies in $\geq 40 \%$ of cells, $\geq 4$ gene copies in $<10 \%$ of cells); low polysomy ( $\geq 4$ gene copies per nucleus in 10 $40 \%$ of cells); high polysomy ( $\geq 4$ gene copies per nucleus in $\geq 40 \%$ of cells) and gene amplification (defined by presence of tight $E G F R$ gene clusters and a ratio of $E G F R$ gene to chromosome of $\geq 2$ or $\geq 15$ copies of $E G F R$ per cell in $\geq 10 \%$ of analysed cells), according to a FISH scoring System defined by Cappuzzo et al. [57]. Amplification and high polysomy were considered as FISH-positive results.

\section{Statistical analysis}

Comparisons were performed using bilateral chi-squared tests or Fisher exact test when needed, because of the small number of lesions in some categories. Anova test was applied to compare the markers expression's percentage.

\section{Results}

\section{Differentiation markers}

Basal cell hyperplasia positive LP34 cells in the lower cell layers revealed clear cut to squamous metaplasia staining up to the top cell layer, by loss of CK7 expression (Table 1, Fig. 1f, g). Accordingly, dysplasias showed always LP34 positivity and CK7 negativity.
Chromogranin A expression was negative in all the cases (Table 1).

Caliciform cell hyperplasia, when present, was negative for LP34 (only the basal cell layer remained positive) and maintained the expression for CK7.

\section{Proliferation (Ki67) and apoptotic (p53) markers}

Significant differences of Ki67 expression were found between basal cell hyperplasia and squamous metaplasia group and dysplasia group cases $(p=0.001)$. Ki67 expression was higher in dysplasia $(p=0.0007)$. There was also found a stepwise increment of expression from basal cell hyperplasias, to squamous metaplasia and dysplasia $(p<0.0001)$. The intense expression of Ki67 (intense positive cases) was shown to have a statistical significant increase from basal cell hyperplasia, to squamous metaplasia and dysplasia $(p=$ 0.0002). (Tables 2 and 3, Fig. 1h). Intense positive cases were observed in $19(57.6 \%)$ dysplasias, $9(22.5 \%)$ metaplasias and one basal cell hyperplasia $(6.25 \%)$. There were no significant differences between the three grades of dysplasia. Despite the intense positive cases observed, moderate expression of Ki67 was the second predominant type of expression in dysplasia (11 cases, 33.3\%). Weak expression of Ki67 was mainly observed for basal cell hyperplasia (8 cases, 50\%) and squamous metaplasia (13 cases, 32.5\%).

An increasing expression for p53 in all the three types of lesions was observed $(p<0.0001)$. P53 expression was significantly higher in dysplasia when compared with basal cell hyperplasias and metaplasias $(p=0.0007)$. Intense positive cases were also more frequent in dysplasia $(p=$ $0.0001)$. In 10 basal cell hyperplasias (62.5\%) and 22 squamous metaplasias (55\%), it was possible to observe a weak p53 expression. An intense expression of p53 was observed in 20 cases $(60.6 \%)$ of dysplasia (Tables 2 and 3, Fig. 1i).

EGFR and C-erbB-2/HER2 protein and gene expression

EGFR immunohistochemical expression was significantly higher in dysplasias when compared with other preneo-
Table 1 LP34, CK7 and chromogranin A expression in preneoplastic lesions

\begin{tabular}{|c|c|c|c|c|c|c|}
\hline & \multicolumn{2}{|l|}{ LP34 } & \multicolumn{2}{|l|}{ CK7 } & \multicolumn{2}{|c|}{ Chromogranin A } \\
\hline & Positive & Negative & Positive & Negative & Positive & Negative \\
\hline \multirow[t]{2}{*}{ Basal cell hyperplasia $n=16$} & 16 & 0 & 0 & 16 & 0 & 16 \\
\hline & $100 \%$ & $0 \%$ & $0 \%$ & $100 \%$ & $0 \%$ & $100 \%$ \\
\hline \multirow[t]{2}{*}{ Squamous Metaplasia $n=40$} & 40 & 0 & 0 & 40 & 0 & 40 \\
\hline & $100 \%$ & $0 \%$ & $0 \%$ & $100 \%$ & $0 \%$ & $100 \%$ \\
\hline \multirow[t]{2}{*}{ Dysplasia $n=33$} & 33 & 0 & 0 & 33 & 0 & 33 \\
\hline & $100 \%$ & $0 \%$ & $0 \%$ & $100 \%$ & $0 \%$ & $100 \%$ \\
\hline
\end{tabular}


Table 2 Ki67, p53, C-erbB-2 and EGFR intensity of expression in preneoplastic lesions

\begin{tabular}{|c|c|c|c|c|c|c|c|c|c|}
\hline \multirow[b]{3}{*}{ Basal cell hyperplasia $(n=16)$} & \multirow[b]{3}{*}{ Negative } & \multirow{2}{*}{\multicolumn{2}{|c|}{$\frac{\mathrm{Ki} 67}{\text { No. }(\%)}$}} & \multirow{2}{*}{\multicolumn{2}{|c|}{$\frac{\mathrm{p} 53}{\text { No. }(\%)}$}} & \multirow{2}{*}{\multicolumn{2}{|c|}{$\frac{\text { C-ErbB-2 }}{\text { No. }(\%)}$}} & \multirow{2}{*}{\multicolumn{2}{|c|}{$\begin{array}{l}\text { EGFR } \\
\text { No. }(\%)\end{array}$}} \\
\hline & & & & & & & & & \\
\hline & & 1 & 6.25 & 1 & 6.25 & 15 & 93.75 & 5 & 31.25 \\
\hline \multirow[t]{3}{*}{ (n) } & + & 9 & 56.25 & 10 & 62.5 & 1 & 6.25 & 9 & 43.75 \\
\hline & ++ & 5 & 31.25 & 5 & 31.25 & 0 & 0 & 1 & 6.25 \\
\hline & +++ & 1 & 6.25 & 0 & 0 & 0 & 0 & 1 & 6.25 \\
\hline \multirow[t]{4}{*}{ Squamous metaplasia $(n=40)$} & Negative & 8 & 20 & 5 & 12.5 & 39 & 97.5 & 6 & 15 \\
\hline & + & 18 & 45 & 22 & 55 & 0 & 0 & 13 & 32.5 \\
\hline & ++ & 9 & 22.5 & 12 & 30 & 1 & 2.5 & 14 & 35 \\
\hline & +++ & 5 & 12.5 & 1 & 2.5 & 0 & 0 & 7 & 17.5 \\
\hline \multirow[t]{4}{*}{ Dysplasia $(n=33)$} & Negative & 0 & 0 & 1 & 3 & 27 & 81.8 & 4 & 12.1 \\
\hline & + & 3 & 9.1 & 8 & 24.2 & 5 & 15.2 & 7 & 21.3 \\
\hline & ++ & 17 & 55.5 & 9 & 27.3 & 1 & 3 & 15 & 45.5 \\
\hline & +++ & 13 & 39.4 & 15 & 45.5 & 0 & 0 & 4 & 12.1 \\
\hline
\end{tabular}

plastic lesions ( $p=0.009$ ) (Tables 2 and 3, Fig. 1j, k, Fig. 2). EGFR IHC expression increased between the three groups of lesions $(p=0.0005)$. The intensity of the expression was higher in the group of dysplasia followed by squamous metaplasia, with 18 (54.5\%) dysplasias showing moderate expression and 3 cases (9.1\%) intense expression, while $14(35 \%)$ squamous metaplasia presented moderate expression and $1(2.5 \%)$ intense expression $(p=0.005)$. Basal cell hyperplasia showed mainly a low EGFR expression, counting ten (62.5\%) cases. Statistical differences between the different grades of dysplasia were not found (Fig. 2). C-erbB-2 protein overexpression was clearly observed in only one severe dysplasia (Tables 2 and 3, Fig. 11), without statistical differences between the three groups of lesions or according to the severity of the dysplasia $(p=0.14)$. C-erbB-2 protein expression was less frequent than EGFR.
EGFR and HER2 gene increased copy number was more often due to polysomy than to amplification. Among the four cases with intense EGFR protein expression, three had high polysomy and one showed disomy.

The number of FISH EGFR positive cases were higher in the group of dysplasia $(p=0.0002)$ (Fig. 3). Statistical significant correlation between EGFR IHC expression and FISH EGFR results was determined when the intensity of IHQ expression (positive intense vs. non-intense positive cases) was considered ( $p=0.0092)$ (Fig. 4).

HER 2 FISH positive cases $(n=4)$ were due to high polysomy. In one case $(n=1)$, high trisomy was observed. All high polysomy cases were identified in CIS cases, and the high trisomy case was identified in a basal cell hyperplasia. These cases were IHC negative. The IHCpositive C-erbB-2 case showed low trisomy and was considered FISH HER2 negative (Fig. 5a, b, c).
Table 3 Ki67, p53, c-erbB-2 and EGFR expression in preneoplastic lesions considering intensity and percentage of cells with expression

\begin{tabular}{|c|c|c|c|c|c|c|c|c|c|}
\hline \multirow[b]{3}{*}{ Basal cell hyperplasia $(n=16)$} & \multirow[b]{3}{*}{ Neg } & \multirow{2}{*}{\multicolumn{2}{|c|}{$\frac{\mathrm{Ki} 67}{\text { No. (\%) }}$}} & \multirow{2}{*}{\multicolumn{2}{|c|}{$\frac{\mathrm{p} 53}{\text { No. }(\%)}$}} & \multirow{2}{*}{\multicolumn{2}{|c|}{$\frac{\text { C-ErbB-2 }}{\text { No. (\%) }}$}} & \multirow{2}{*}{\multicolumn{2}{|c|}{$\begin{array}{l}\text { EGFR } \\
\text { No. (\%) }\end{array}$}} \\
\hline & & & & & & & & & \\
\hline & & 2 & 12.5 & 1 & 6.25 & 15 & 93.75 & 5 & 31.25 \\
\hline \multirow{4}{*}{ Squamous metaplasia $(n=40)$} & Low pos & 8 & 50 & 10 & 62.5 & 1 & 6.25 & 10 & 62.5 \\
\hline & Mod pos & 5 & 31.25 & 2 & 12.5 & 0 & 0 & 1 & 6.25 \\
\hline & Pos int & 1 & 6.25 & 3 & 18.75 & 0 & 0 & 0 & 0 \\
\hline & Neg & 13 & 32.5 & 5 & 12.5 & 39 & 97.5 & 6 & 15 \\
\hline \multirow{3}{*}{ 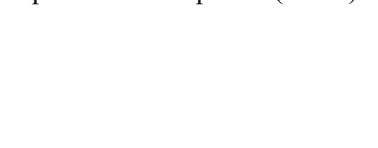 } & Low pos & 13 & 32.5 & 22 & 55 & 0 & 0 & 19 & 47.5 \\
\hline & Mod pos & 5 & 12.5 & 4 & 10 & 1 & 2.5 & 14 & 35 \\
\hline & Pos int & 9 & 22.5 & 9 & 22.5 & 0 & 0 & 1 & 2.5 \\
\hline \multirow[t]{4}{*}{ Dysplasia $(n=33)$} & Neg & 0 & 0 & 1 & 3 & 27 & 81.8 & 4 & 12.2 \\
\hline & Low pos & 3 & 9.1 & 8 & 24.2 & 5 & 15.2 & 8 & 24.2 \\
\hline & Mod pos & 11 & 33.3 & 4 & 12.2 & 1 & 3 & 18 & 54.5 \\
\hline & Pos int & 19 & 57.6 & 20 & 60.6 & 0 & 0 & 3 & 9.1 \\
\hline
\end{tabular}




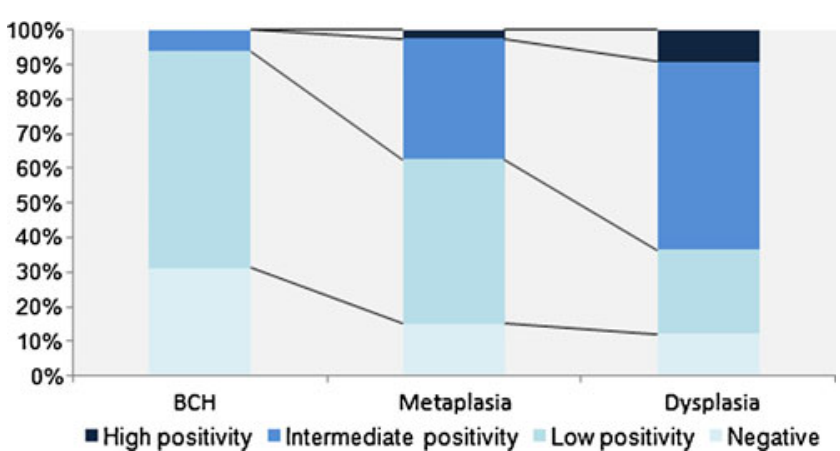

Fig. 2 (MS Excell) Immunohistochemical EGFR expression between the preneoplastic lesions

\section{Discussion}

As lung carcinogenesis is a multistep process, preneoplastic or preinvasive bronchial lesions' evolution to bronchial carcinoma depends upon the molecular and genetic abnormalities accumulated in time. Those abnormalities increase from the normal bronchial epithelium through basal cell hyperplasia, squamous metaplasia and low-grade to highgrade dysplasia. Certain proteins and genes play key roles in lung carcinogenesis and their aberrant expression in that process makes them as potential biomarkers susceptible to discriminate a subpopulation of patients with particularly active mutagenesis, progressive cancerization process and at very high risk to develop lung cancer [58].

LP34, CK7, chromogranin A, Ki67, p53, EGFR and CerbB2 were the seven biomarkers chosen for this study as their abnormal expression is related with the oncogenic process. The first three were used successfully as differentiation markers of the preneoplastic lesions.

A basal cell origin for basal hyperplasia, squamous metaplasia and dysplasia was clearly defined, based on LP34 and CK7 expression. Immunohistochemical differentiation markers like LP34, CK7 and chromogranin A demonstrated useful to discriminate preneoplastic lesions

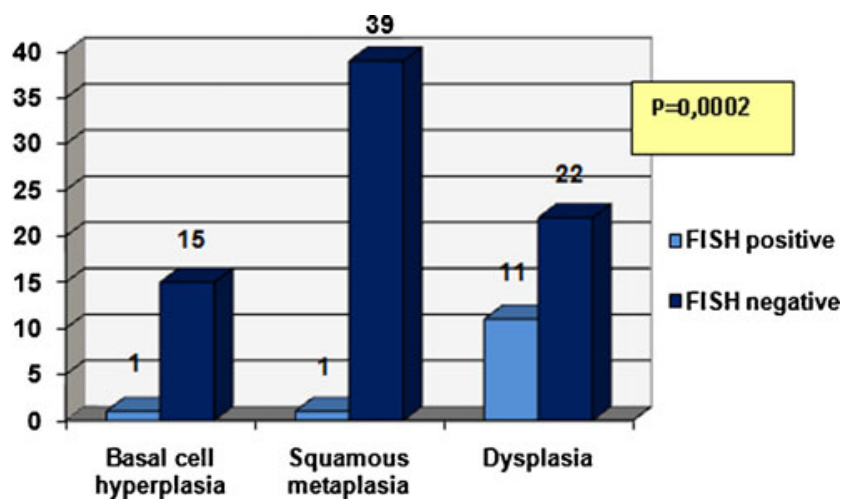

Fig. 3 (MS Excell) EGFR FISH results according to preneoplastic lesions

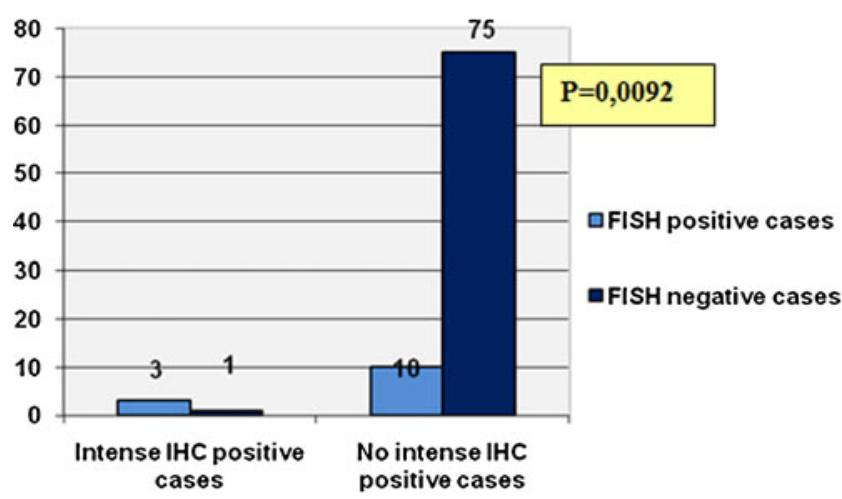

Fig. 4 (MS Excell) Correlation between immunohistochemical EGFR expression and FISH results

from other proliferative lesions like caliciform cell hyperplasia or neuroendocrine cell hyperplasia. As expected, basal cell hyperplasia and squamous metaplasia are always LP34-positive and CK7 and chromogranin A-negative, indicating basal cell origin and conditioning squamous cell carcinoma as a basal cell carcinoma. In contrast, caliciform cell hyperplasia maintains cytoplasmic CK7 positivity cells and inconstant LP34 membrane positivity, reflecting an origin in cylindrical cells of the upper cell layer of the respiratory epithelium in bronchial adenocarcinoma carcinogenesis. Chromogranin A, a neuroendocrine marker, was constantly negative in this study, emphasizing that neuroendocrine cell hyperplasia has a different cell commitment.

Ki67 expression stepwise increment reflects the increasing proliferative index observed in the spectrum of preneoplastic lesions. The statistical higher expression observed in dysplasia group compared to basal cell hyperplasia and squamous metaplasia defines two groups of lesions according to their proliferative index. As other authors observed, the intensity of Ki67 expression is also higher in dysplasia. This way, we reinforce the utility of Ki67 as a biomarker, namely for dysplasia, as it appears as a group characterized by high proliferative index, subscribing the literature and other authors' study of preneoplastic lesions [22-26, 59].

P53, the "guardian" maintaining the integrity of the genome by participating in the DNA damage checkpoints in the cell cycle, regulating cellular proliferation and apoptosis [20], has been detected in preneoplastic lesions of the lung, suggesting that it occurs early during lung carcinogenesis $[14,18,20]$ as the obtained results confirmed. P53 expression was significantly higher in dysplasia when compared with hyperplasia and metaplasia, and the intensity of expression was also higher in the dysplasia group, supporting p53 accumulation involvement in the development of squamous cell lung cancer and fixing p53 as a remarkable biomarker in lung carcinogenesis.

There are many studies concerning EGFR, C-erbB-2, Ki67 and p53 expression in lung cancer. However, there are 

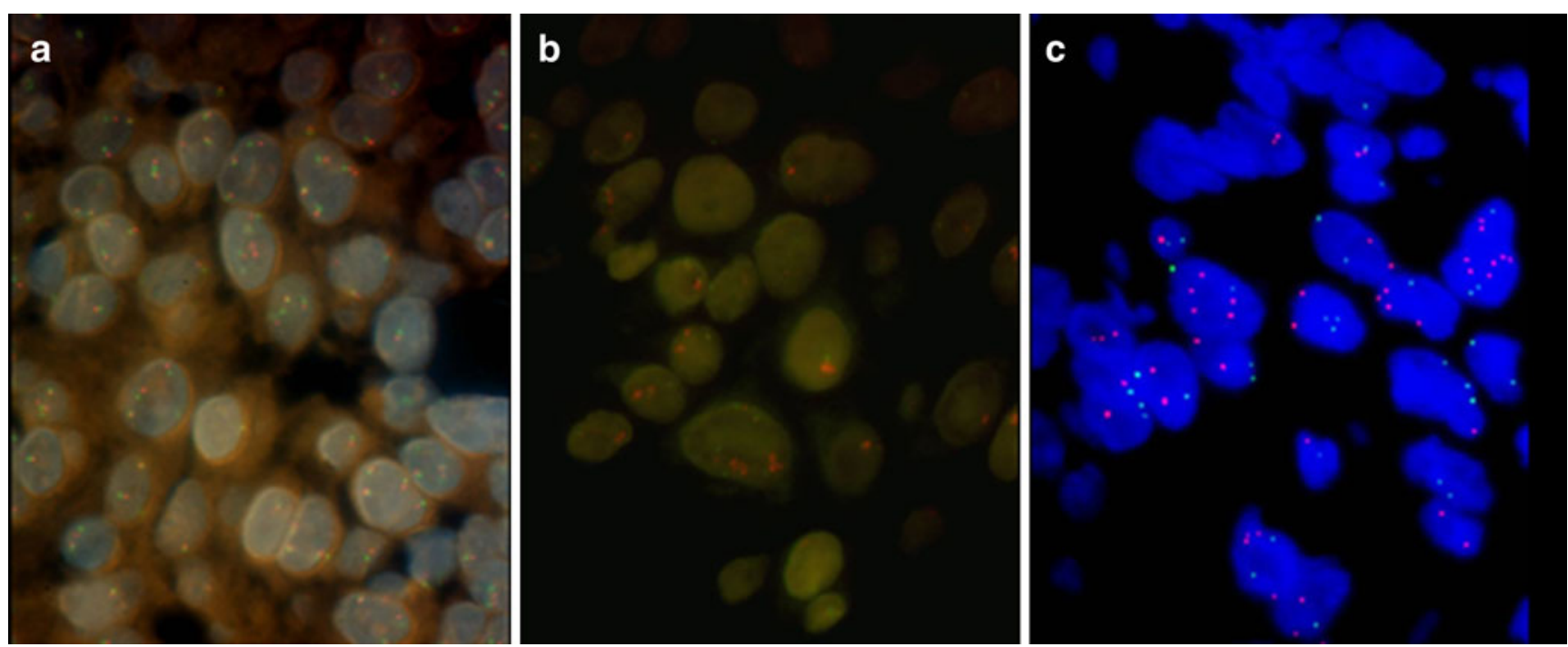

Fig. 5 a Dual-colour FISH assay with EGFR (red) and chromosome 7 (green), balanced polysomy, $\times 1,000$. b Dual-colour FISH assay with EGFR (red) and chromosome 7 (green), amplification, $\times 1,000$. c

fewer results validating these markers in preneoplastic lesions and most of them used only immunochemistry techniques. By analysing the expression of those biomarkers, using not only immunohistochemistry but also feasible molecular techniques, such as FISH and correlating the results obtained by the two different techniques, bronchial preneoplastic lesions achieve prognostic significance.

EGFR immunohistochemical increased expression in preneoplastic lesions, increasing from basal cell hyperplasia to dysplasia, had been demonstrated [6, 7, 21, 38-42, 55, 60]. Meert et al. [21] also demonstrated not only an increasing EGFR rate from normal bronchial epithelium to CIS and microinvasive tumours, but also a statistically significant cut off between mild dysplasia and severe dysplasia. Although the greater expression has been seen in dysplasia, statistical differences between the different grades of dysplasia were not demonstrated (probably because the number of cases of dysplasia was limited).

$E G F R$ high gene copy number was due more frequently to polysomy than to amplification. FISH-positive EGFR cases are present in all types of preneoplastic lesions and were higher in dysplasia group. Polysomy appears as an early event in the sequence of hyperplasia-metaplasiadysplasia. The higher frequency of polysomy in preneoplastic lesions is reflected in the high frequency of this event in squamous cell carcinomas, constituting the earliest molecular event in lung carcinogenesis [17, 22, 41].

EGFR protein was overexpressed in all lesions with an increased gene copy number. There was statistical significant correlation between EGFR immunohistochemical expression and FISH EGFR results, when considering the intensity of IHC expression [17]. Therefore, it was demonstrated that
Dual-colour FISH assay with HER2neu (red) and chromosome 17 (green), amplification, $\times 1,000$

protein expression does reflect high gene copy number, like polysomy and amplification. Although EGFR gene amplification is implicated as one mechanism for EGFR overexpression, it does not seem to be the main one [61].

Despite an increasing expression of EGFR and Ki67 along the spectrum of preneoplastic lesions, no correlation between the two markers was found. Meert et al. recently described that low-grade lesions showed no EGFR or Ki67 expression contrasting with high-grade lesions. EGFR overexpression is associated with cell proliferation, making EGFR an early marker of malignant transformation in lung carcinogenesis [21, 38, 59].

C-erbB-2 immunohistochemical overexpression is less frequent than EGFR overexpression, supporting the minor role of C-erbB-2 in squamous cell carcinogenesis when compared with EGFR [17, 62]. In our study, only one case of severe dysplasia showed C-erbB-2-positive immunohistochemical expression and polysomy was observed in $70 \%$ of the cells. C-erB-2 FISH-positive cases were due to high polysomy, showing that amplification is less frequent as a high gene copy number event. No statistical significant correlation was obtained between $C$-erbB-2 gene and protein expression.

C-erB-2 does not seem to be involved in the first steps of lung carcinogenesis [16]. For Piyathilake et al., the expression of C-erbB-2 was significantly higher in squamous cell carcinoma and associated precancerous lesions than in normal epithelium and hyperplastic lesions, but no stepwise expression of C-erbB-2 was observed, suggesting its lack of importance in the squamous cell lung carcinogenesis [38]. HER2/neu increased copy number is observed in approximately $35 \%$ of adenocarcinomas and slightly less 
frequently in squamous cell carcinomas [18], assuming more importance in the development of lung adenocarcinomas. The increased copy number of $H E R 2 / n e u$ in NSCLC is most often attributable to chromosome duplication and polysomy [50], rather than amplification [18].

Although EGFR and Ki67 expression increases from normal epithelium to preinvasive lesions together, this was not seen for C-erbB-2. Therefore, any correlation between EGFR and Ki67 expressions and C-erbB-2 expression was established, like other studies also registered [21, 41, 6366]. Interestingly, other studies revealed that EGFR/HER2/ neu heterodimerization expression is capable to induce a stronger and more sustained proliferative signal than EGFR homodimers [60, 62].

The need to accurate detection of the EGFR and HER2/ neu gene copy number and protein overexpression, reflecting their importance as biomarkers in squamous cell pathogenesis, has become even more important because despite recent advances in lung cancer treatments, improvement in survival has only been modest, showing that effective therapeutic and early detection approaches are still lacking [38]. Selection of patients with preneoplastic lesions expressing selected biomarkers is the way to provide new and more effective strategies for early diagnosis, a posterior closer follow-up and eventually chemoprevention and targeted treatment with better safety profiles. A variety of new approaches that target selected biomarkers in lung carcinogenesis are in clinical development or have already been approved for second and third line lung cancer treatment [5, 52-56, 67].

Our comparison between gene copy number and protein expression contributes to define which are the most reliable methods to be used in patient selection. Since our study includes a large number of preneoplastic lesions in a different population analysed by two different techniques (IHC and FISH), the results obtained reinforce other results published before, some of them centred only in one molecular marker and/or have used a single technique, which measures either the protein level or the gene expression. By identifying dysplasia as a group of preneoplastic lesions, chemoprevention targeted schemes can be delineated to select individual patients, considering protein expression, gene copy number and gene mutational status with repercussions in drug sensitivity.

\section{Conclusions}

We conclude that squamous cell carcinoma preneoplastic lesions studied have a basal cell origin, as demonstrated by the unbalance between LP34 and CK7. The differentiation markers, LP34, CK7 and chromogranin A, successfully discriminate preneoplastic lesions origin.
Dysplasias showed a higher expression of EGFR, Ki67 and p53 with a stepwise expression with the gravity of the preneoplastic lesions, reflecting their importance as potential biomarkers of preinvasive lesions of the bronchial epithelium and may be used to identify patients with a higher risk of developing squamous cell lung carcinoma. C-erbB-2 immunohistochemical overexpression is a rare event in bronchial preneoplastic lesions, emphasizing the minor role of C-erbB-2 as a biomarker in squamous cell carcinogenesis.

EGFR and HER2/neu high gene copy number was present in preneoplastic lesions, with a higher EGFR gene copy number in dysplasias. EGFR and HER2/neu high gene copy number was due to polysomy more often than to amplification, reinforcing that amplification is not the main mechanism for protein overexpression. Although $\mathrm{HER} 2 / \mathrm{neu}$ does not seem to be involved in the early steps of squamous cell lung carcinogenesis, HER2/neu gene copy number is important because this gene is a HER family member and an important heterodimerizarion partner for EGFR.

Biological/genetic markers associated with several molecular and genetic abnormalities, such as Ki67, p53, EGFR and HER2/neu, need to be validated as potential and useful preneoplastic bronchial lesion biomarkers. Risk assessment should be based not only on smoking consumption and on histopathology of bronchial lesions, but also on the basis of in situ molecular biomarkers [58]. Therefore, in the future, the recognition of those biomarkers will allow a targeted screening and a posterior closer follow-up to select patients for chemoprevention schemes and will have a positive impact on survival.

Acknowledgements The authors would like to thank Isabel Carreira and Paula António.

Conflicts of interest We declare that we have no conflict of interest.

\section{References}

1. Doll R, Peto R (1981) The causes of cancer: quantitative estimates of avoidable risks of cancer in the United States today. J Natl Cancer Inst 66:1191-1308

2. Shopland DR (1995) Tobacco use and its contribution to early cancer mortality with a special emphasis on cigarette smoking. Environ Health Perspect 103(Suppl 8):131-142

3. Devereux TR, Taylor JA, Barrett JC (1996) Molecular mechanisms of lung cancer. Interaction of environmental and genetic factors. Giles F. Filley Lecture. Chest 109:14S-19S

4. Jemal A, Murray T, Samuels A, Ghafoor A, Ward E, Thun MJ (2003) Cancer statistics, 2003. CA Cancer J Clin 53:5-26

5. Winterhalder RC, Hirsch FR, Kotantoulas GK, Franklin WA, Bunn PA Jr (2004) Chemoprevention of lung cancer-from biology to clinical reality. Ann Oncol 15:185-196

6. Meert AP, Martin B, Delmotte P, Berghmans T, Lafitte JJ, Mascaux C et al (2002) The role of EGF-R expression on patient survival in lung cancer: a systematic review with meta-analysis. Eur Respir J 20:975-981 
7. Herbst RS, Bunn PA Jr (2003) Targeting the epidermal growth factor receptor in non-small cell lung cancer. Clin Cancer Res 9:5813-5824

8. Shigematsu H, Lin L, Takahashi T, Nomura M, Suzuki M, Wistuba II et al (2005) Clinical and biological features associated with epidermal growth factor receptor gene mutations in lung cancers. J Natl Cancer Inst 97:339-346

9. Travis WD (1999) Histological Classification of Lung and Pleural Tumors. International Histological Classification of Tumors, Berlin, PA

10. Auerbach O, Forman JB, Gere JB, Kassouny DY, Muehsam GE, Petrick TG et al (1957) Changes in the bronchial epithelium in relation to smoking and cancer of the lung; a report of progress. $\mathrm{N}$ Engl J Med 256:97-104

11. Colby TV (1999) Precursor lesions to pulmonary neoplasia. In: Brambilla C, Brambilla E (eds) Lung Tumours. Fundamental Biology and Clinical Management (pp. 61-87). Marcel Dekker Inc, New York, PA

12. Wistuba II, Behrens C, Milchgrub S, Bryant D, Hung J, Minna JD et al (1999) Sequential molecular abnormalities are involved in the multistage development of squamous cell lung carcinoma. Oncogene 18:643-650

13. Franklin WA (2000) Pathology of lung cancer. J Thorac Imaging $15: 3-12$

14. Piyathilake CJ, Frost AR, Manne U, Weiss H, Heimburger DC, Grizzle WE (2003) Nuclear accumulation of p53 is a potential marker for the development of squamous cell lung cancer in smokers. Chest 123:181-186

15. Rowinsky EK (2003) Signal events: cell signal transduction and its inhibition in cancer. Oncologist 8(Suppl 3):5-17

16. Peters EJ, Morice R, Benner SE, Lippman S, Lukeman J, Lee JS et al (1993) Squamous metaplasia of the bronchial mucosa and its relationship to smoking. Chest 103:1429-1432

17. Hirsch FR, Varella-Garcia M, Bunn PA Jr, Di Maria MV, Veve R, Bremmes RM et al (2003) Epidermal growth factor receptor in non-small-cell lung carcinomas: correlation between gene copy number and protein expression and impact on prognosis. J Clin Oncol 21:3798-3807

18. Giaccone G (1996) Oncogenes and antioncogenes in lung tumorigenesis. Chest 109:130S-134S

19. Fong KM, Sekido Y, Minna JD (1999) Molecular pathogenesis of lung cancer. J Thorac Cardiovasc Surg 118:1136-1152

20. Kohno T, Yokota J (1999) How many tumor suppressor genes are involved in human lung carcinogenesis? Carcinogenesis 20:14031410

21. Meert AP, Verdebout JM, Martin B, Ninane V, Feoli F, Sculier JP (2003) Epidermal growth factor receptor expression in preinvasive and early invasive bronchial lesions. Eur Respir J 21:611-615

22. Hirano T, Franzen B, Kato H, Ebihara Y, Auer G (1994) Genesis of squamous cell lung carcinoma. Sequential changes of proliferation, DNA ploidy, and p53 expression. Am J Pathol 144:296-302

23. Li ZH, Zheng J, Weiss LM, Shibata D (1994) c-k-ras and p53 mutations occur very early in adenocarcinoma of the lung. Am J Pathol 144:303-309

24. Betticher DC, Heighway J, Thatcher N, Hasleton PS (1997) Abnormal expression of CCND1 and RB1 in resection margin epithelia of lung cancer patients. Br J Cancer 75:1761-1768

25. Satoh Y, Ishikawa Y, Nakagawa K, Hirano T, Tsuchiya E (1997) A follow-up study of progression from dysplasia to squamous cell carcinoma with immunohistochemical examination of $\mathrm{p} 53$ protein overexpression in the bronchi of ex-chromate workers. $\mathrm{Br} \mathrm{J}$ Cancer 75:678-683

26. Brambilla E, Gazzeri S, Lantuejoul S, Coll JL, Moro D, Negoescu A et al (1998) p53 mutant immunophenotype and deregulation of p53 transcription pathway (Bcl2, Bax, and Waf1) in precursor bronchial lesions of lung cancer. Clin Cancer Res 4:1609-1618
27. Sugio K, Kishimoto Y, Virmani AK, Hung JY, Gazdar AF (1994) $\mathrm{K}$-ras mutations are a relatively late event in the pathogenesis of lung carcinomas. Cancer Res 54:5811-5815

28. Hung J, Kishimoto Y, Sugio K, Virmani A, McIntire DD, Minna JD et al (1995) Allele-specific chromosome 3p deletions occur at an early stage in the pathogenesis of lung carcinoma. JAMA 273:1908

29. Kishimoto Y, Sugio K, Hung JY, Virmani AK, McIntire DD, Minna JD et al (1995) Allele-specific loss in chromosome 9p loci in preneoplastic lesions accompanying non-small-cell lung cancers. J Natl Cancer Inst 87:1224-1229

30. Wistuba II, Behrens C, Virmani AK, Milchgrub S, Syed S, Lam S et al (1999) Allelic losses at chromosome 8p21-23 are early and frequent events in the pathogenesis of lung cancer. Cancer Res 59:1973-1979

31. Wistuba II, Lam S, Behrens C, Virmani AK, Fong KM, LeRiche J et al (1997) Molecular damage in the bronchial epithelium of current and former smokers. J Natl Cancer Inst 89:1366-1373

32. Franklin WA, Wistuba II, Geisinger K, Lam S, Hirsh FR (2004) Squamous dysplasia and carcinoma in situ. In Travis WD, Brambilla E, Müller-Hermelink HK, \& Harris CK (Eds.) Tumours of the lung, pleura, thymus and heart. Pathology and genetics. pp. 68-72. Lyon, PA: IARC Press

33. Stoscheck CM, King LE Jr (1986) Role of epidermal growth factor in carcinogenesis. Cancer Res 46:1030-1037

34. Berger MS, Gullick WJ, Greenfield C, Evans S, Addis BJ, Waterfield MD (1987) Epidermal growth factor receptors in lung tumours. J Pathol 152:297-307

35. Sobol RE, Astarita RW, Hofeditz C, Masui H, Fairshter R, Royston I et al (1987) Epidermal growth factor receptor expression in human lung carcinomas defined by a monoclonal antibody. J Natl Cancer Inst 79:403-407

36. Prenzel N, Fischer OM, Streit S, Hart S, Ullrich A (2001) The epidermal growth factor receptor family as a central element for cellular signal transduction and diversification. Endocr Relat Cancer 8:11-31

37. Yarden Y, Sliwkowski MX (2001) Untangling the ErbB signalling network. Nat Rev Mol Cell Biol 2:127-137

38. Piyathilake CJ, Frost AR, Manne U, Weiss H, Bell WC, Heimburger DC et al (2002) Differential expression of growth factors in squamous cell carcinoma and precancerous lesions of the lung. Clin Cancer Res 8:734-744

39. Rusch V, Baselga J, Cordon-Cardo C, Orazem ZM, Hoda S et al (1993) Differential expression of the epidermal growth factor receptor and its ligands in primary non-small cell lung cancers and adjacent benign lung. Cancer Res 53:2379-2385

40. Kurie JM, Shin HJ, Lee JS, Morice RC, Ro JY, Lippman SM et al (1996) Increased epidermal growth factor receptor expression in metaplastic bronchial epithelium. Clin Cancer Res 2:1787-1793

41. Franklin WA, Veve R, Hirsch FR, Helfrich BA, Bunn PA Jr (2002) Epidermal growth factor receptor family in lung cancer and premalignancy. Semin Oncol 29:3-14

42. Lonardo F, Dragnev KH, Freemantle SJ, Ma Y, Memoli N, Sekula $\mathrm{D}$ et al (2002) Evidence for the epidermal growth factor receptor as a target for lung cancer prevention. Clin Cancer Res 8:54-60

43. Hirsch FR, Franklin WA, Veve R, Varella-Garcia M, Bunn PA Jr (2002) HER2/neu expression in malignant lung tumors. Semin Oncol 29:51-58

44. Beerli RR, Hynes NE (1996) Epidermal growth factor-related peptides activate distinct subsets of ErbB receptors and differ in their biological activities. J Biol Chem 271:6071-6076

45. Pinkas-Kramarski R, Soussan L, Waterman H, Levkowitz G, Alroy I, Klapper L et al (1996) Diversification of Neu differentiation factor and epidermal growth factor signaling by combinatorial receptor interactions. EMBO J 15:2452-2467

46. Graus-Porta D, Beerli RR, Daly JM, Hynes NE (1997) ErbB-2, the preferred heterodimerization partner of all ErbB receptors, is a mediator of lateral signaling. EMBO J 16:1647-1655 
47. Bongiorno PF, Whyte RI, Lesser EJ, Moore JH, Orringer MB, Beer DG (1994) Alterations of K-ras, p53, and erbB-2/neu in human lung adenocarcinomas. J Thorac Cardiovasc Surg 107:590-595

48. Tateishi M, Ishida T, Kohdono S, Hamatake M, Fukuyama Y, Sugimachi K (1994) Prognostic influence of the co-expression of epidermal growth factor receptor and c-erbB-2 protein in human lung adenocarcinoma. Surg Oncol 3:109-113

49. Brabender J, Danenberg KD, Metzger R, Schneider PM, Park J, Salonga D et al (2001) Epidermal growth factor receptor and HER2-neu mRNA expression in non-small cell lung cancer Is correlated with survival. Clin Cancer Res 7:1850-1855

50. Bunn PA Jr, Helfrich B, Soriano AF, Franklin WA, Varella-Garcia M, Hirsch FR et al (2001) Expression of Her-2/neu in human lung cancer cell lines by immunohistochemistry and fluorescence in situ hybridization and its relationship to in vitro cytotoxicity by trastuzumab and chemotherapeutic agents. Clin Cancer Res 7:3239-3250

51. Lai WW, Chen FF, Wu MH, Chow NH, Su WC, Ma MC et al (2001) Immunohistochemical analysis of epidermal growth factor receptor family members in stage I non-small cell lung cancer. Ann Thorac Surg 72:1868-1876

52. Khuri FR (2003) Primary and secondary prevention of non-smallcell lung cancer: the SPORE Trials of Lung Cancer Prevention. Clin Lung Cancer 5(Suppl 1):S36-S40

53. Khuri FR, Cohen V (2004) Molecularly targeted approaches to the chemoprevention of lung cancer. Clin Cancer Res 10:4249s$4253 \mathrm{~s}$

54. Hirsch FR, Lippman SM (2005) Advances in the biology of lung cancer chemoprevention. J Clin Oncol 23:3186-3197

55. Meert AP, Martin B, Verdebout JM, Ninane V, Sculier JP (2005) Does c-erbB-2 play a role in the first steps of lung carcinogenesis? Anticancer Res 25:2005-2008

56. Saba NF, Khuri FR (2005) Chemoprevention strategies for patients with lung cancer in the context of screening. Clin Lung Cancer 7:92-99

57. Cappuzzo F, Hirsch FR, Rossi E, Bartolini S, Ceresoli GL, Bemis $\mathrm{L}$ et al (2005) Epidermal growth factor receptor gene and protein and gefitinib sensitivity in non-small-cell lung cancer. J Natl Cancer Inst 97:643-655
58. Jeanmart M, Lantuejoul S, Fievet F, Moro D, Sturm N, Brambilla $\mathrm{C}$ et al (2003) Value of immunohistochemical markers in preinvasive bronchial lesions in risk assessment of lung cancer. Clin Cancer Res 9:2195-2203

59. Meert AP, Martin B, Verdebout JM, Feoli F, Mascaux C, Ninane $\mathrm{V}$ et al (2006) EGFR, c-erbB-2 and ki-67 in NSCLC and preneoplastic bronchial lesions. Anticancer Res 26:135-138

60. Scagliotti GV, Selvaggi G, Novello S, Hirsch FR (2004) The biology of epidermal growth factor receptor in lung cancer. Clin Cancer Res 10:4227s-4232s

61. Atkins D, ReiffenKA TCL, Winther H, Bonato MS, Storkel S (2004) Immunohistochemical detection of EGFR in paraffinembedded tumor tissues: variation in staining intensity due to choice of fixative and storage time of tissue sections. J Histochem Cytochem 52:893-901

62. Onn A, Correa AM, Gilcrease M, Isobe T, Massarelli E, Bucana CD et al (2004) Synchronous overexpression of epidermal growth factor receptor and HER2-neu protein is a predictor of poor outcome in patients with stage I non-small cell lung cancer. Clin Cancer Res 10:136-143

63. Giatromanolaki A, Koukourakis MI, O'Byrne K, Kaklamanis L, Dicoglou C, Trichia E et al (1996) Non-small cell lung cancer: cerbB-2 overexpression correlates with low angiogenesis and poor prognosis. Anticancer Res 16:3819-3825

64. Reinmuth N, Brandt B, Kunze WP, Junker K, Thomas M, Achatzy R et al (2000) Ploidy, expression of erbB1, erbB2, P53 and amplification of erbB1, erbB2 and erbB3 in non-small cell lung cancer. Eur Respir J 16:991-996

65. Kanematsu T, Yano S, Uehara H, Bando Y, Sone S (2003) Phosphorylation, but not overexpression, of epidermal growth factor receptor is associated with poor prognosis of non-small cell lung cancer patients. Oncol Res 13:289-298

66. Meert AP, Feoli F, Martin B, Verdebout JM, Mascaux C, Verhest A et al (2004) Ki67 expression in bronchial preneoplastic lesions and carcinoma in situ defined according to the new $1999 \mathrm{WHO} /$ IASLC criteria: a preliminary study. Histopathology 44:47-53

67. Hirsch FR, Scagliotti GV, Langer CJ, Varella-Garcia M, Franklin WA (2003) Epidermal growth factor family of receptors in preneoplasia and lung cancer: perspectives for targeted therapies. Lung Cancer 41(Suppl 1):S29-S42 